\title{
THE USE OF POST-ACQUISITION EVIDENCE IN SECTION 7 CONGLOMERATE MERGER CASES
}

In recent years, section 7 of the Clayton Act $^{1}$ has been wielded with vigor by the Federal Trade Commission in its attack upon conglomerate mergers. ${ }^{2}$ As the assault has been pressed against untested combinations, the courts reviewing the Commission's actions have faced difficult questions concerning the weight to be given evidence depicting the affected markets after the merger. This issue, which was somewhat ambiguously treated by the Supreme Court recently in FTC v. Consolidated Foods Corp., ${ }^{3}$ seems likely to face the Court again

\footnotetext{
1 Prior to amendment in 1950, the essence of $\$ 7$ was:

$[N]$ o corporation engaged in commerce shall acquire, directly or indirectly, the whole or any part of the stock or other share capital of another corporation engaged also in commerce, where the effect of acquisition may be to substantially lessen competition between the corporation whose stock is so acquired and the corporation making the acquisition, or to restrain such commerce in any section or community, or tend to create a monopoly of any line of commerce.
}

38 Stat. 731 (1914). The remainder of the statute established exceptions to this rule, including an exception for acquisitions made purely for investment.

The amended statute, 64 Stat. 1125 (1950), 15 U.S.C. $\$ 18$ (1964), the heart of which is quoted in the text accompanying note 5 infra, applies to asset acquisitions as well as stock acquisitions, prohibits all mergers whose effect will be "substantially to lessen competition," rather than just those which lessen competition between acquiring and acquired firms, and refers only to commerce in any section of the country. S. Rep. No. 1775, 81st Cong., 2d Sess. 3 (1950).

For commentary on this revision, see Hernacki, Mergerism and Section 7 of the Clayton Act, 20 Geo. WASE. L. Rev. 659 (1952) ; Comment, 64 Harv. L. Rev. 1212 (1951) ; Comment, 46 ILI. L. REv. 444 (1951).

2 In the FTC's petition for a writ of certiorari in the Procter \& Gamble case, it was argued that

the Commission's limited resources for merger enforcement are heavily committed to conglomerate mergers involving firms in related product lines. It recently found one unlawful in General Foods Corp., 3 CCH Trade Reg. Rep., $\pi 17,465$, relying heavily on its opinion in the instant case. An earlier decision invalidating a similar merger was affirmed in Ekco Products Co. v. Federal Trade Commission, 347 F.2d 745 (C.A. 7). See, also, Reynolds Metals Co. v. Federal Trade Commission, 309 F.2d 223 (C.A. D.C.); cf. Federal Trade Commission v. Consolidated Foods Corp., 380 U.S. 592. And the Commission has a number of other, similar acquisitions under active investigation with a view to issuance of formal complaints.

Petition for Certiorari, pp. 9-10, Procter \& Gamble Co. v. FTC, 358 F.2d 74 (6th Cir.), cert. granted, 385 U.S. 897 (1966).

The Department of Justice has concurrent authority with the FTC to enforce $\$ 7$ if it chooses to file a complaint in the appropriate district court. S. REP. No. 1775 , 81st Cong., 2d Sess. 3 (1950). The Federal Trade Commission has been the main watchdog over conglomerate mergers, however, and this Comment will consider post-acquisition evidence in the context of FTC investigation only.

3380 U.S. 592 (1965). See text accompanying notes $37-45$ infra. 
in the pending case, FTC v. Procter \& Gamble Co. ${ }^{4}$ This Comment will illustrate the usefulness of such post-acquisition evidence, examine some of the difficulties engendered by its use and suggest some guidelines by which the courts might review such use by the FTC.

\section{The Usefulness of Post-Acquisition Evidence}

Section 7 of the Clayton Act, ${ }^{5}$ as amended in 1950, provides in relevant part:

$[N]$ o corporation engaged in commerce shall acquire, directly or indirectly, the whole or any part of the stock or other share capital and no corporation subject to the jurisdiction of the Federal Trade Commission shall acquire the whole or any part of the assets of another corporation engaged also in commerce, where in any line of commerce in any section of the country, the effect of such acquisition may be substantially to lessen competition, or to tend to create a monopoly.

Initially, it should be noted that all mergers challenged under this statute are subject to the same standard: whether "the effect of such acquisition may be substantially to lessen competition, or to tend to create a monopoly." This standard was designed by Congress "to cope with the monopolistic tendencies in their incipiency and well before they have attained such effects as would justify a Sherman Act proceeding." " In implementing this intent, however, Congress did not outlaw mergers in which there is only a "mere possibility" of injury. An acquisition is not within the reach of section 7 until there is a "reasonable probability" of the proscribed effects. ${ }^{7}$ By thus dispensing with the necessity of proving actual harm, section 7 demands a prediction; the Commission must forecast future anticompetitive effects which are likely to be caused by the merger. ${ }^{8}$ Since by definition a prediction entails an element of uncertainty, this legislative decision means that in the course of preventing many undesirable mergers, a few mergers that would not eventually have proven to be harmful will also be prevented. Given the desirability of minimizing this chance

4385 U.S. 897 (1966), granting cert. in 358 F.2d 74 (6th Cir. 1966). The FTC in the petition for certiorari attacked the Sixth Circuits reasoning in attaching "great weight to the post-acquisition evidence in the record." P. 14. See the discussion of this evidence in text accompanying notes 48-49 infra.

564 Stat. 1125 (1950), 15 U.S.C. $\$ 18$ (1964).

6 S. REP. No. 1775, 81st Cong., 2d Sess. 4 (1950).

7 Id. at 6 . Any requirement of certainty or actuality of injury would obviously be inconsistent with Congress' effort to supplement the Sherman Act by stopping the proscribed consequences before harm can be done.

8 The Commission, in making its determination, must act in conformity with the Administrative Procedure Act, 5 U.S.C. $\$ \$ 551-59,701-06$ (Supp. -), and the findings of the Commission as to the facts are to be conclusive if supported by substantial evidence. S. REP. No. 1775, 81st Cong., 2d Sess. 6-7 (1950). 
of error, evidence of the actual effects of an acquisition might be helpful in estimating its true potential. ${ }^{9}$ That is, where the pre-merger information about the merging companies and their markets is susceptible to a variety of plausible inferences about the potential impact of the merger, the post-acquisition history may tend to demonstrate that certain of these possibilities have materialized and are likely to continue, but that other possibilities are unlikely to materialize. For example, if one set of reasonable pre-acquisition inferences forecasts the likelihood that television advertising economies will substantially increase the market power of the merged firms, evidence of the failure of an intensive promotional campaign significantly to affect the market would tend to

9 If the probabilities of a merger had to be judged at the time of acquisition, any use of post-acquisition evidence might seem to be logically irrelevant since what happens after a merger does not change what the probabilities were at the time of acquisition. In United States v. E. I. du Pont de Nemours \& Co., 353 U.S. 586 (1957), however, the Supreme Court rejected the contention that the reasonable probabilities must be measured at the time of acquisition. Mr. Justice Brennan, speaking for the Court, noted:

To accomplish the congressional aim, the Government may proceed at any time that an acquisition may be said with reasonable probability to contain a threat that it may lead to a restraint of commerce or tend to create a monopoly of a line of commerce. Even when the purchase is solely for investment, the plain language of $\$ 7$ contemplates an action at any time the stock is used to bring about . . . the substantial lessening of competition.

Id. at 597-98. Thus, in cases where the Government claims the reasonable probability exists at the time of suit, post-acquisition evidence is as relevant as pre-acquisition evidence in measuring the probabilities.

Moreover, even when the Government's suit is predicated upon the theory that the probability existed at the time of acquisition, a strictly logical exclusion of postacquisition evidence is too extreme. Since it is often difficult to recognize a merger's true probabilities purely on the basis of pre-acquisition evidence (see text accompanying notes 17-26 inf ra), post-acquisition evidence would seem to be relevant to the extent that it "relates back"-i.e., it reveals what the probabilities were at the time of acquisition. Authority for this proposition is found in $\mathrm{Mr}$. Justice Burton's dissent in $d u$ Pont. Although Mr. Justice Burton strongly disagreed with the majority's opinion that "time of suit" rather than "time of acquisition" was controlling, he did acknowledge that post-acquisition evidence "is relevant to the extent that it bears on the central question whether, at the time of acquisition, there was a reasonable probability of a threat to competition." 353 U.S. at 625 .

It is still uncertain how far the FTC will attempt to carry the "time of suit" interpretation. Some doubt was cast upon the vitality of the doctrine by the second Procter \& Gamble opinion:

[T] charged with the enforcement of Section 7 should be obvious. If the agencies postpone the commencement or completion of the action challenging a merger in order to see what trends or results will stem from it, they thereby disable themselves from obtaining or granting effective relief. It bears repeating that an order divesting corporate assets that were acquired a long time before the issuance of the order rarely advances the policies of Section 7.

Procter \& Gamble Co., 3 Trade Reg. Rep. (1963-65 Transfer Binder) \|16,673, at 21,574-75 (FTC 1963).

For commentary supporting the "time of suit" interpretation, see, e.g., Stedman, The Merger Statute: Sleeping Giant or Sleeping Beauty, 52 N N. U.L. REv. 567, 576-85 (1957) ; 5 U.C.L.A.L. Rev. 120, 122 (1958) ; 106 U. PA. L. Rev. 116, 120-23 (1957). For commentary disapproving the "time of suit" interpretation, see Manne, The Perplexing Du Pont Case: Additional Confusion in the Law of Mergers, 106 J. PA. L. Rev. 385, 393-94 (1958) ; The Supreme Court, 1956 Term, 71 HARv. L. Rev. $85,167-68$ (1957); Note, 66 YaLe I.J. 1251, 1259-66 (1957). 
undermine the strength of such inferences. This is not to say that postacquisition evidence will always or even often be so helpful, but where it does accurately demonstrate some potential of the merger it may reduce the chance of predictive error.

It would seem that post-acquisition evidence would have its greatest utility where a conglomerate merger is involved. While such evidence might also be helpful in analyzing horizontal or vertical mergers, ${ }^{10}$ judgments as to these mergers can be more accurately made on the basis of pre-merger evidence than can judgments as to conglomerate mergers. ${ }^{11}$ The difference in predictive accuracy is largely attributable to the pre-merger market contact that characterizes horizontal and vertical mergers. This phenomenon is absent in conglomerate mergers since, by definition, a conglomerate merger involves firms that have not been related as competitors or as buyer and seller.

In the horizontal and vertical cases, the pre-merger relationship of the acquiring and acquired firms facilitates the expression of probabilities in quantitative terms. For example, in a horizontal merger, ${ }^{12}$ if the present market is shared equally by five firms, the merger of firms $A$ and $B$ can be readily seen as likely to result in AB's possessing $40 \%$ of the market if both firms simply maintain their present activity. Similarly, in a vertical merger, ${ }^{13}$ if five sellers equally share a market and buyer $\mathrm{X}$ constitutes $40 \%$ of that market, the probable result of buyer X's merging with seller A is quickly demonstrable: whereas B, $\mathrm{C}, \mathrm{D}$ and $\mathrm{E}$ formerly competed with $\mathrm{A}$ for all the market, $\mathrm{X}$ is now likely to give its entire business to $A$, thereby foreclosing $B, C, D$ and

10 See Turner, Conglomerate Mergers and Section 7 of the Clayton Act, 78 Harv. L. Rev. 1313, 1315 (1965). Turner distinguishes among the three types of mergers -horizontal, vertical and conglomerate-in the following manner.

[W] may define the area of conglomerate mergers as all acquisitions other than (1) acquisition by a producer of the stock or assets of a firm producing an identical product or close substitute and selling it in the same geographical market-the simple horizontal merger; and (2) acquisition of the stock or assets of a firm that buys the product sold by the acquirer or sells a product bought by the acquirer-the simple vertical merger.

The variety of conglomerate mergers ranges from the pure conglomerate, involving no discernible economic relationship between the merging companies, through several kinds of "mixed conglomerates," which evidence indirect horizontal or vertical relationships. For examples of mixed conglomerates, see note 17 infra.

11 In comparing the three categories of mergers, Turner concludes that in a conglomerate merger the anticompetitive effects "can rarely if ever be so obvious or so certain" as in the case of horizontal mergers and some cases of vertical mergers. Id. at $1321-22$.

12 See, e.g., United States v. Von's Grocery Co., 384 U.S. 270 (1966) ; United States v. Continental Can Co., 378 U.S. 441 (1964); United States v. Aluminum Co. of America, 377 U.S. 271 (1964); United States v. First Nat'1 Bank \& Trust Co., 376 U.S. 665 (1964); United States v. Philadelphia Nat'l Bank, 374 U.S. 321 (1963) ; Brown Shoe Co. v. United States, 370 U.S. 294 (1962).

13 See, e.g., Brown Shoe Co. v. United States, supra note 12; United States v. E. I. du Pont de Nemours \& Co., 353 U.S. 586 (1957) ; cf. Reynolds Metals Co. v. FTC, 309 F.2d 223, 229 (D.C. Cir. 1962) (vertical integration involved in merger, but FTC's $\$ 7$ finding not based on this factor). 
E from competing for that $40 \%$ share. ${ }^{14}$ Whether or not this emphasis upon market shares is appropriate as the sole measure of the legality of horizontal and vertical mergers, it is clear that "the Supreme Court has come to place important if not decisive weight on the share of the relevant markets controlled by the acquiring and acquired companies." 15 An approach predicated upon the analysis of market shares is not possible in conglomerate merger cases, however, because market shares in two unrelated markets do not lead to the same inferences that can be drawn from market shares in the same or a vertically related market. ${ }^{16}$ Examination of the tests used by the FTC in Procter \& Gamble will illustrate this point.

In 1957, Procter \& Gamble Company, the nation's largest producer of domestic cleansers, purchased the total assets of the Clorox Chemical Company, the dominant manufacturer of liquid household bleach. This acquisition constituted a product-extension merger, ${ }^{17}$ the acquisition by one producer of a noncompeting but complementary producer, with possibilities of research, production and marketing integration. ${ }^{18}$ After five years of hearings and appeals, the FTC-in a seventy-four-page opinion by Commissioner Elman-ordered divestiture. $^{19}$ The FTC concluded that the merger would be likely to have

14 The vertical judgment is slightly more difficult than the horizontal judgment because foreclosure will only result if $X$ changes its buying habits; the trier must assess the likelihood of this change. See Turner, supra note 10, at 1321-22.

15 Id. at 1315. See, e.g., United States v. Continental Can Co., 378 U.S. 441, 459-62 (1964); United States v. Aluminum Co. of America, 377 U..S. 271, 278-80 (1964); United States v. Philadelphia Nat'1 Bank, 374 U.S. 321, 364-66 (1963); Brown Shoe Co. v. United States, 370 U.S. 294 (1962). But see United States v. Von's Grocery Co., 384 U.S. 270 (1966) (Court's emphasis almost entirely upon the number of firms in the market rather than the market shares of any particular firm).

${ }_{16}$ Turner, sipra note 10 , at 1316, after noting the use of market share figures in horizontal and vertical cases, concludes that "whatever significance can be attached to market shares in these cases, quite clearly the significance becomes less when we deal with conglomerate mergers, and indeed may completely vanish."

17 A product-extension merger is only one type of conglomerate merger. Other "mixed conglomerate" characteristics include: 1) market extension-the acquisition of a firm producing the same product as the acquirer but selling it in another market, see, e.g., United States v. EI Paso Natural Gas Co., 376 U.S. 651 (1964); 2) reciprocity-a buyer's conditioning his order upon the seller's purchase of the products of the buyer's merged subsidiary. See, e.g., FTC v. Consolidated Foods Corp., 380 U.S. 592 (1965). Similar to a conglomerate merger is a "joint venture," the intercorporate formation of a third corporation designed to fulfill economic needs of the two parent corporations. See, e.g., United States v. Penn-Olin Chemical Co., 378 U.S. 158 (1964).

18 In the Procter \& Gamble-Clorox merger, the major possibilities of integration were at the marketing level. Liquid detergent bleach, a caustic soda solution, is $53 / 4 \%$ hyperchlorite and $941 / 4 \%$ water. The manufacturing process is relatively simple, but the weight of the product, which must be shipped in liquid form, reduces the feasible shipping radius to 300 miles from the point of manufacture. The major economies of this merger would allegedly be realized in advertising expenditures since Procter \& Gamble, the nation's largest advertiser in 1957, was already skilled in marketing low-cost domestic cleansers. Procter \& Gamble Co. v. FTC, 358 F.2d 74, 79 (6th Cir. 1966).

10 Procter \& Gamble Co., 3 Trade Reg. ReP. (1963-65 Transfer Binder) $\pi 16,673$ (FTC 1963). This was the second time the Commission had acted upon the Procter \& Gamble case. In a 1961 appeal by Procter \& Gamble, the Commission had remanded the case to the trial examiner for the gathering of post-acquisition evidence. Procter \& Gamble Co., 58 F.T.C. 1203 (1961). See note 47 infra. 
three principal undesirable effects: 1) increased concentration in the bleach industry by virtue of Procter \& Gamble's superior financial resources; 2) decreased possibilities of future deconcentration in the bleach industry due to raised entry barriers; and 3) the removal of a significant restraint on Clorox's anticompetitive conduct by virtue of the elimination of Procter \& Gamble as a potential competitor. ${ }^{20}$ Clearly an assessment of such probabilities on the basis of pre-merger evidence necessitates theoretical judgments uncalled for in horizontal and vertical cases. Determination of the likelihood of "increased concentration" 21 requires analysis not just of market shares, but of the importance of capital and technique in improving market performance, the availability of Procter \& Gamble's applicable resources and the willingness of the acquirer substantially to divert these resources. Employment of the entry barrier test ${ }^{22}$ involves speculations as to the previous barrier, the added retaliation potential resulting from the merger and the degree to which this increase will deter possible new entrants. ${ }^{23}$ The potential competitor test condemns the removal by merger of Clorox's most feared potential competitor-Procter \& Gamble-when Procter \& Gamble's presence outside the market had restrained Clorox from exploiting its market position. ${ }^{24}$ The difficult inferences which must be drawn in order to apply the potential competitor test include: whether

20 Reply Brief for Respondent, p. 4, Procter \& Gamble Co. v. FTC, 358 F.2d 74 (6th Cir. 1966). Commissioner Elman discusses these effects in Procter \& Gamble Co., 3 Trade Reg. Rep. (1963-65 Transfer Binder) $\pi 16,673$, at 21,575-86 (FTC 1963).

21 For commentary on the anticompetitive and pro-competitive effects of a conglomerate merger upon present competitors, see Blair, The Conglomerate Merger in Economics and Law, 46 GEo. L.J. 672, 679-94 (1958); Turner, sipra note 10, at $1322-62$.

22 For an extensive discussion of the entry barrier problem, see BaIN, BARRIERs to New Competrition (1956).

${ }_{23}$ Turner, in discussing the likelihood and consequences of a conglomerate merger's raising the barriers to entry into an industry, observes that "it is virtually impossible to estimate the probabilities of significant adverse effects upon entry." Turner, supra note 10 , at 1356.

24 There are actually two possible ways in which the removal of potential competition may have an anticompetitive effect. The effect mentioned in the text results because the dominant firm no longer fears inducing entry by presenting too attractive a market picture. It therefore begins to exploit its monopolistic advantages. Turner finds this the most persuasive reason for outlawing a conglomerate merger if three preconditions are present: 1) the market must be an oligopoly, 2) the outsider must have been recognized as one of few likely entrants, and 3 ) the price level at which entry would be induced must not be above the profit-maximizing level. Once these minimum conditions have been established, however, the problem of proving substantiality remains, and Turner acknowledges that "in the absence of the kind of direct proof found in El Paso [the market-extension merger cited in note 17 supra], it obviously becomes more difficult to determine the existence and substantiality of the competitive influence of a firm not actually selling in the market." Turner, supra note 10 , at 1371 .

The other way in which the removal of potential competition by merger may have an anticompetitive effect is if the outside firm would have entered the market by internal expansion but for the merger. See id. at 1362-86. Throughout the Procter $\&$ Gamble proceedings there is confusion between these two effects, but in its petition for certiorari, the FTC emphasized the first effect, removal of a deterrent to anticompetitive behavior. Petition for Certiorari, pp. 15-17, Procter \& Gamble Co. v. FTC, 358 F.2d 74 (6th Cir.), cert. granted, 387 U.S. $897^{\prime}$ (1966). 
Clorox was in fact restrained by its lower-priced competitors rather than by potential entrants; whether Procter \& Gamble was regarded as a threatening entrant to the point of restraint; and whether there are other firms-e.g., Colgate-Palmolive-which might fill the same role after the merger.

Adding to the difficulty of assessing the probable consequences of a conglomerate merger is the fact that many of the tests attempt in part to measure psychological reactions. ${ }^{25}$ For example, the entry barrier is not merely the investment needed to gain recognition in the present market; that amount is affected by the fact that present competitors will intensify their competitive efforts to resist the intrusion of the new competitors. Thus in part the effect of an entry barrier depends upon an "outsider's" assessment of an "insider's" reaction to new competition. Similarly, the restraining influence of a potential competitor upon a present competitor's conduct depends upon the present competitor's judgment of the point at which the potential competitor will think the market attractive enough to warrant entry. In this latter situation, the psychological factor is an "insider's" judgment of an "outsider's" reactions. Consequently in both the entry barrier test and the potential competitor test, measurements of future psychological factors are crucial to a section 7 prediction. Such measurements are not easily made on the basis of the pre-acquisition evidence available at an FTC hearing.

Thus it would seem that in conglomerate merger cases, the inferences to be drawn from pre-merger evidence are both more various and more tenuous than in horizontal and vertical merger cases, and the chances of predictive error are correspondingly higher. If post-acquisition evidence which accurately speaks to the potential of the merger were available, it would be especially useful in conglomerate merger cases.

There is a strong argument, however, that too thorough an investigation of economic evidence in pursuit of maximum accuracy may result in great inefficiency of administration without greatly reducing the chances of predictive error. ${ }^{26}$ This argument rests primarily on the

25 In its second opinion, the Commission carefully noted:

[T] he conditions which retard competition in an industry are to an important degree psychological. They stem from competitors' appraisal of each other's intentions, rather than from the intentions-or the actions taken upon themthemselves.

Procter \& Gamble Co., 3 Trade Reg. ReP. (1963-65. Transfer Binder) II 16,673, at 21,579 (FTC 1963). See Blair, supra note 21, at 690, 692-93 (discussing psychological effect on present competition); Turner, supra note 10, at 1357 (entry barriers are "largely a psychological phenomenon") \& 1364 (discussing the mechanics of "potential entrant" deterrence). But see id. at 1353-54 (suggesting that where the industry is already highly oligopolistic, the effect on the behavior of present competitors is unlikely to reduce competition).

26 For the leading treatment of this issue, see Bok, Section 7 of the Clayton Act and the Merging of Law and Economics, 74 Harv. L. Rev. 226 (1960). Professor Bok urges the development of simple, clear rules designed to reduce the complexity of investigation. For a discussion of rules that might be used for conglomerate mergers, see Turner, supra note 10. 
premises that: a) the adversary system is not well suited to the analysis of complex economic theories and statistics; b) even if all the relevant economic standards were assembled, economists as well as lawyers lack the knowledge to make sophisticated predictions; and c) in view of (a) and (b), the marginal value of broadening the scope of inquiry is minimal. ${ }^{27}$ The argument concludes that the danger of choking the administrative process with too much evidence may be especially great with respect to post-acquisition evidence since the relationship of particular effects to a particular merger is likely to be obscure. ${ }^{28}$

Balancing considerations of administrative efficiency against the possible usefulness of post-acquisition evidence, however, does not require excluding all such evidence merely because some of it would not be helpful. A section 7 attack upon a merger is an extraordinary proceeding; it enables the government to order divestiture without any proof that such a combination has been, or necessarily will be, harmful. A prediction made on the basis of almost incomprehensible economic data is sufficient to deprive a corporation of any benefit from a carefully planned multi-million dollar transaction and to force that corporation to disentangle assets which may have become greatly intertwined. To deny the corporation the use of all post-acquisition evidence may subject it to a most severe penalty when an examination of what actually happened after the merger might clarify an admittedly obscure mass of pre-merger inferences. This is not to say that a corporation should be allowed to postpone a hearing in order to accumulate such evidence, but rather that if helpful evidence is available, it should be used. The problem of administrative inefficiency should be solved by strictly confining the use of post-acquisition evidence to the circumstances in which it will be genuinely reliable.

\section{The Weight To Be Given Post-Acouisition Evidence}

There are two major circumstances in which post-acquisition evidence should not be afforded any weight in a section 7 case. The first is when it does not accurately reflect the effect of the acquisition because it is not responsive to the trier's test, i.e., it is not probative. The second is when it does not accurately reflect the effect of the acquisition because it has been manipulated so as to present a misleading impression.

\section{Probativeness}

As with all other evidence, post-acquisition evidence must be probative before it can be given weight by the Commission. In a section 7 case, if evidence is introduced to illustrate the anticompetitive effect of a merger, it is probative only if that effect would not have

27 Bok, supra note 26, at 228, 238-47, 287-99.

28 See Commissioner Elman's opinion in Procter \& Gamble Co., 3 Trade REG. REP. (1963-65 Transfer Binder) $\| 16,673$, at 21,574 (FTC 1963). 
occurred but for the merger. For example, if the FTC alleges that the effect of the merger is the lessening of deconcentration possibilities by virtue of a raised entry barrier, evidence that no new firms have entered the market is probative-tends to prove the allegationonly if it can be shown that new firms would have entered but for the merger. Similarly, if the effect to be shown is increased concentration, evidence that several competitors have dropped out of a market after a merger is probative only if it can be shown that such firms would not have dropped out had there been no merger.

Evidence introduced by the respondent in defense of a merger must also meet the test of probativeness. A corporation will often introduce post-acquisition evidence in an attempt to demonstrate the error of the FTC predictions. Since section 7 does not demand certainty or actuality of injury, evidence merely showing that anticompetitive effects have not yet materialized is not, in itself, probative. Only evidence tending to show that the FTC predictions are unlikely to be realized in the future speaks genuinely to section 7's purpose of stopping restrictive practices in their incipiency. For example, evidence introduced at an FTC hearing two years after a merger, depicting no increase in the market share of the merged firms, is responsive to the "increased concentration" test only if the trier can reasonably infer from it an improbability of future increased concentration. ${ }^{20}$

Evidence depicting "active" consequences contrary to the trier's prediction lends itself more easily to a responsive inference than does evidence of "passive" consequences. For example, if the corporate respondent attempts to rebut an allegation of probable increased concentration by introducing evidence of the failure of an intensive advertising and price-cutting campaign, the inference that future concentration increases are improbable is stronger than if the respondent simply shows that two years have passed with no anticompetitive effects.

\section{Manipulation}

The corporate respondent's position in using post-acquisition evidence is strikingly different from that of the government. The government is an "outsider" utilizing evidence of what happened after the merger to substantiate a prediction of anticompetitive consequences. On the other hand, the respondent is an "insider" utilizing the actual effects of an acquisition to refute the prediction. The position of the respondent as one in control of evidence makes such evidence suspect because of the possibility that the respondent has restrained himself merely for purposes of proof.

29 The same considerations apply to all evidence merely showing an absence of the alleged effects, though it would seem that the longer the period of absence, the stronger should be the inferences which can be drawn from mere absence of anticompetitive effects. 
Manipulation in this context does not mean that the respondent will introduce evidence which it knows to be untrue, such as doctored financial statements. Rather we are dealing with the possibility that the corporation, knowing that it was under investigation, has refrained from exploiting its market position, thereby making the post-merger record misleading as to the true probable effects of the merger. ${ }^{30}$

It does not follow from this premise that all evidence favorable to the respondent is suspect because of the possibility of manipulation. ${ }^{31}$ Evidence that was not within the control of the accused, such as a competitor's conduct, obviously could not have been manipulated. Such evidence should be admissible. ${ }^{32}$ Conversely, if post-acquisition evidence reflects a pro-competitive change so substantial that the value of the investment is seriously jeopardized, such evidence should also be admissible. In such a situation, the chance that manipulation has occurred seems slight.

The bulk of post-acquisition evidence, however, is still open to the suspicion of corporate restraint. There are four possible ways in which the admissibility of such evidence can be treated: 1) the FTC must conclusively prove the evidence to have been manipulated;2) the FTC must prove that it is more probable than not that the evidence was manipulated; 3 ) any evidence designated "suspicious" by the FTC is rebuttably presumed to have been manipulated; 4) any evidence designated suspicious by the FTC is conclusively presumed to have been manipulated.

The first alternative seems unrealistically severe in view of the subtle nature of the proof required; it is an almost impossible task to prove conclusively that a company deliberately restrained itself in its course of conduct. ${ }^{33}$ Lowering the standard to "more probable than not," as in the second alternative, is not much better. The evidence which would be needed by the government to demonstrate that intrafirm decisions and orders were made with deliberate restraint in fear of section 7 proceedings is within the power of the company. Any company desirous of influencing post-acquisition evidence would have

$30 \mathrm{It}$ is also possible that the pre-merger record could be manipulated in anticipation of a merger. Two circumstances make this unlikely: a) the absence of internal control over both merging companies, and b) less awareness of $\$ 7$ vulnerability. The combination of these two circumstances means that the preparation of a favorable evidentiary framework would require comprehensive cooperative planning, making the proof of suspected pre-merger manipulation less difficult than proof of postacquisition manipulation. Such cooperation between two firms might also violate the Sherman Act "restraint of trade" provision. 26 Stat. 209 (1890), as amended, 15 U.S.C. $\$ 1$ (1964).

31 Concern over manipulation should be restricted to evidence favorable to the acquisition.

32 Even this approval must be used with caution, however, since it is conceivable that a competitor's conduct was possible only because the merging company refrained from retaliating in order to make the merger appear harmless.

33 See, e.g., MCCormick, Evidence \& 318, at 675 (1954); 9 Wigmore, Evmence $\S 2486$ (3d ed. 1940). 
little difficulty making evidence of such intentions unavailable. Thus the result of either the first or the second alternatives would be to admit a great amount of unreliable post-acquisition evidence. In addition to the danger of inaccuracy, there is the substantial risk that the administrative process may choke on its own consumption of evidence. ${ }^{34}$ Though the fear of choking the administrative process is not in itself a sufficient reason generally to exclude probative post-acquisition evidence, it certainly weighs against a liberal policy of admitting evidence that is already inherently suspicious.

But if a presumption that evidence has been manipulated should be available to the FTC, we must still consider whether that presumption should be rebuttable or conclusive. While a conclusive presumption at first glance seems unduly strict, there are good arguments in its favor. Allowing a company to attempt to demonstrate that the favorable evidence within its control has not been manipulated may be opening a Pandora's box of proofs. The amount of available postacquisition evidence is often overwhelming, and the efficient administration of section 7 could be frustrated by liberal rules of evidence that would delay resolution of these cases by creating unwieldy records. One of the reasons for not placing the burden of proof on the FTC in section 7 cases was to preserve the prophylactic purpose of the section by ensuring prompt processing of complaints. Allowing respondents to introduce the subtle proof required to show an absence of manipulation may be letting in through the window what was shut out at the door.

On the other hand, in view of the usefulness of post-acquisition evidence in conglomerate merger cases, ${ }^{35}$ it would be putting a heavy burden on respondents to force them to rebut section 7 accusations without the chance to use important evidence merely because it might have been manipulated. The vast bulk of probative post-acquisition evidence is subject to the merging companies' control and thus, at least, colorably suspicious. In view of the FTC commitment to antitrust prosecution, ${ }^{36}$ allowing the Commission unilateral, conclusive determination of this issue may well mean denying corporate respondents use of their most effective weapon without any opportunity to demonstrate its legitimacy. Stripped of their defenses, the merged firms would be forced to retreat to a battle of economic theories and conjectures about the future. This development hardly seems consistent with a desire to reduce to a minimum the amount of speculation inherent in a section 7 judgment.

Consequently it would appear that the potential usefulness of postacquisition evidence controlled by the respondents outweighs the need

34 See text accompanying notes 26-28 supra.

35 See text accompanying notes 10-24 sipra.

36 See note 2 supra. 
for expedience to the extent that the FTC should be allowed only a rebuttable presumption. Since the burden of showing an absence of manipulation is an extremely difficult one, the effect may be to prevent respondents from using most of the post-acquisition evidence available to them. This result is perfectly consistent, however, with the desire to protect the efficiency of the administrative process while giving the respondent the chance to use those crucial pieces of reliable evidence that may protect his investment against an erroneous prediction.

\section{The Cases}

The Supreme Court has been faced with the question of the use of post-acquisition evidence in a conglomerate merger case only once, in FTC v. Consolidated Foods Corp. ${ }^{37}$ As noted earlier, ${ }^{38}$ it is difficult to draw definite conclusions from that decision. In Consolidated Foods Corp., ${ }^{39}$ the FTC had disallowed the acquisition of Gentry, Inc., an onion and garlic producer, by the Consolidated Foods Corporation, a food processor and distributor. The Commission found that the market structure resulting from the merger raised a substantial probability of reciprocity, and that consequently the merger violated section 7. Reciprocity is essentially the result of a firm's saying to one of its suppliers, "I will not buy from you unless you buy some of your supplies from my subsidiary." 40 On appeal, the Court of Appeals for the Seventh Circuit held that the divestiture order was not supported by substantial evidence. The decision relied heavily upon ten years of post-acquisition evidence. ${ }^{41}$

The majority of the Supreme Court, in an opinion by Mr. Justice Douglas, stated that, while it was not improper for the lower court to consider post-acquisition evidence, too much weight had been given to such evidence in this case:

No group acquiring a company . . . is entitled to a "free trial" period. To give it such would be to distort the scheme of $\S 7 .$. . If the post-acquisition evidence were given

37380 U.S. 592 (1965). For commentary on this case, see Donnelly, The Supreme Court-The Federal Trade Commission and the Not-So-Conglomerate Merger: An Analysis of Federal Trade Commission v. Consolidated Foods Corp., 43 U. DET. L.J. 35 (1965); The Supreme Court, 1964 Term, 79 Harv. L. REv. 56, 181-85 (1965); Note, 44 Texas L. Rev. 1019 (1966).

38 See text accompanying note 3 supra.

393 TRADE REG. REP. (1961-63 Transfer Binder) \16,182 (FTC 1962), reซ'd, 329 F.2d 623 (7th Cir. 1964), rev'd, 380 U.S. 592 (1965).

40 See, e.g., Harsha, The Conglomerate Merger and Reciprocity-Condenned by Conjecture?, 9 Antatrust Bull. 201 (1964); Hausman, Reciprocal Dealing and the Antitrust Laws, 77 HARv. L. REv. 873 (1964) ; Krash, The Legality of Reciprocity Under Section 7 of the Clayton Act, 9 Antitrust Bull. 93 (1964); Turner, supra note 10 , at $1386-93$.

41 The court of appeals' opinion concluded: "Probability can best be gauged by what the past has taught. We are convinced that the Commission has mistakenly rejected what the record demonstrates as to the past in favor of a future possibility based on conjecture and speculation." 329 F.2d at 627 . 
conclusive weight or allowed to override all probabilities, then acquisitions would go forward willy-nilly, the parties biding their time until reciprocity was allowed fully to bloom. ${ }^{42}$

It is uncertain just why Mr. Justice Douglas characterized the postmerger period as a "free trial" period. ${ }^{43}$ The kernel of his thought is apparently contained in the phrase "the parties biding their time until reciprocity was allowed fully to bloom." Despite the difficulty of understanding this phrase in the context of the passage, the thrust of the majority's concern would seem to be that the "clean record" presented by the first few post-merger years might blind the trier to the true potentiality of the acquisition. ${ }^{44} \mathrm{Mr}$. Justice Stewart, in his concurring opinion, was far more concerned with the need for such evidence:

No one gives the company a "free trial" by assessing, in light of what actually happened, what could only be hypotheses at the time the merger occurred. Without post-acquisition evidence, the trier is faced with a blank slate and untested speculation. . . . We may be sure that the Commission relied on post-acquisition factors in issuing its order; there is no reason why we should rely on those factors less in assessing the propriety of the Commission's action. Indeed, if anyone had a "free trial" period to check the anticompetitive potential of the merger, it was not the respondent but the Commission. ${ }^{45}$

42380 U.S. at 598.

Donnelly, supra note 37, after extensive analysis of the Consolidated Foods situation, concludes that $\mathrm{Mr}$. Justice Douglas attempted to bring about a compromise between the FTC and the court of appeals. The Commission had urged in its brief that the thrust of $\$ 7$ was at market structure, not market behavior, and that postacquisition evidence was only admissible either to buttress a conclusion of anticompetitive structure or to show that the alleged anticompetitive effects would be impossible within that structure. Brief for Petitioner, pp. 47-49, FTC v. Consolidated Foods Corp., 380 U.S. 592 (1965). See generally Procter \& Gamble Co., 3 TRAdE REg. Rep. (1963-65 Transfer Binder) $\pi 16,673$, at 21,572-74 (FTC 1963). On the other hand, the court of appeals had emphasized the behavior following the merger: "No substantial impact on the relevant market occurred, and absent some factor which requires a different approach we are of the view that the experience reflected by this post-acquisition period must weigh heavily in appraising future probabilities." 329 F.2d at 626 .

43 See The Supreme Court, 1964 Term, 79 HARv. L. Rev. 56, 183 (1965), which suggests that Mr. Justice Douglas' statement implies that post-acquisition evidence may be used to prove the illegality of a merger, but not its legality.

44 See also Donnelly, supra note 37 , at 66-67, 77-78, suggesting that the Court, dealing with an unfamiliar problem, "quite properly refrained from stifling future development by spelling out in its own opinions at too early a stage the precise standards for judging the lawfulness of such mergers." Id. at 78. Donnelly further suggests that the Commission may be able to reconcile the Court's demand to consider post-acquisition behavior with the basically structural approach developed by the FTC in its opinions in Procter \& Gamble and Consolidated Foods, and in Reynolds Metals Co., 56 F.T.C. 743 (1960), aff'd, 309 F.2d 223 (D.C. Cir. 1962).

45380 U.S. at 606 (concurring opinion). Mr. Justice Stewart concurred on the basis of evidence that the smaller food processors shifted orders to Consolidated in response to the influence of reciprocity. This evidence was not referred to in the majority opinion. 
Thus, Mr. Justice Stewart fears not that the trier will be blinded by looking at a "clean record," but rather that a trier will be blinded to the extent that he must rely on "untested speculation" without the guidance of the actual results of the merger.

The suggestions concerning probativeness and manipulation discussed above would seem to accommodate the concerns of both the majority and concurring opinions in Consolidated Foods. The danger of a "free trial" period is mitigated by the strict requirement of probativeness, and by allowing the FTC a rebuttable presumption against the admissibility of any evidence thought to have been manipulated. ${ }^{46}$ On the other hand, any post-acquisition evidence that really speaks to the future probabilities of the merger is available to stabstantiate or refute pre-merger hypotheses and thus to increase the accuracy of section 7 administration.

The Procter \& Gamble case may provide a second chance for the Supreme Court to consider the problem of post-acquisition evidence in conglomerate merger cases. ${ }^{47}$ By the time the briefs had been submitted to the Sixth Circuit in Procter \& Gamble's appeal, Consolidated Foods had been decided. Procter \& Gamble, in its brief, contended that two sets of post-acquisition statistics "refute the contention that . . . [the merger] has or would be the cause of any lessening of competition or any tendency to monopoly in the liquid bleach industry." 48 The first set of statistics illustrated that Clorox's postmerger growth continued at approximately the same pace as its premerger growth. The second set illustrated that, after the merger,

46 These standards will also operate to regulate the amount of evidence that will have to be examined and will thus help to avoid the problems of inefficiency considered in the text accompanying notes 26-28 supra.

47 The nine-year history of the Procter \& Gamble case reflects the confusion over post-acquisition evidence that has plagued the prosecution of conglomerate mergers. The complaint against Procter \& Gamble was the Commission's first major attack against a conglomerate merger. When the hearing examiner's initial decision was appealed by Procter \& Gamble to the Commission in 1960, the case was remanded for the gathering of additional evidence because "the record as presently constituted does not provide an adequate basis for determining the legality of this acquisition." Procter \& Gamble Co., 58 F.T.C. 1203, 1206 (1961). The examiner was requested to get information on "the competitive situation as it presently exists in the liquid bleach industry." Id. at 1207. After the examiner again recommended divestiture, the Commission upon appeal heard reargument on all contested issues of law and fact presented by the entire record. In its opinion recommending divestiture, the Commission stated that post-acquisition evidence is admissible only in the event of an unusual change in the market structure or where the adverse effects of the merger have become apparent. Procter \& Gamble Co., 3 TRADE REg. ReP. (1963-65 Transfer Binder) \16,673, at 21,574 (FTC 1963). The opinion concluded: "Where, as here, the period since the acquisition has been relatively uneventful, there is certainly no basis for according particular weight to the post-acquisition evidence that found its way, needlessly, into the record." Id. at 21,587. In its brief before the Sixth Circuit, pp. 27-30, the Commission justified this change in position by referring to the Supreme Court's emphasis on probabilities instead of actualities in two cases which had been handed down in the interim-United States v. Philadelphia Nat'1 Bank, 374 U.S. 321 (1963) ; Brown Shoe Co. v. United States, 370 U.S. 294 (1962).

48 Brief for Appellant, p. 74, Procter \& Gamble Co. v. FTC, 358 F.2d 74 (6th Cir. 1966). 
Clorox's competitors had higher dollar and volume sales than ever before. ${ }^{49}$

The court of appeals, in finding that the FTC divestiture order was not supported by substantial evidence, stated that "the Commission was in error in ruling that post-merger evidence was admissible only in unusual cases and that it crept into the record needlessly in the present case, and in giving it no weight." 50 The court also carefully cited both sets of statistics offered by Procter \& Gamble ${ }^{51}$ and stated that the Commission's contention of manipulation was "pure conjecture." 52 This treatment of the post-acquisition evidence was attacked as one of the three major errors in the lower court opinion when the FTC petitioned the Supreme Court for a writ of certiorari. ${ }^{53}$ Thus, the issue of the weight to be accorded post-acquisition evidence will probably be faced by the Court again.

$49 I d$. at $73-80$.

$50358 \mathrm{~F} .2 \mathrm{~d}$ at 82.

51 Id. at 80,82 .

$52 I d$. at 83.

53 Petition for Certiorari, pp. 11-14, FTC v. Procter \& Gamble Co., 358 F.2d 74 (6th Cir.), cert, granted, 385 U.S. 897 (1966). The other alleged errors were the court of appeals' substitution of its own prediction for those of the Commission, and the court's insistence upon proof that Procter \& Gamble would in fact exercise its power on behalf of Clorox. 